Informasi - ISSN (p) 0126-0650; ISSN (e) 2502-3837

Vol. 50, No. 1 (2020), pp. 58-70, doi: http://doi.org/10.21831/informasi.v50i1. 27842

\title{
Hyperreality study of hijab fashion celebrity
}

\author{
Fitria Angeliqa \\ Communication Science Faculty, Universitas Pancasila, Jakarta, Indonesia \\ 'fitria.angeliqa.17@gmail.com
}

Fizzy Andriani

Communication Science Faculty, Universitas Prof. Dr. Moestopo (Beragama), Jakarta, Indonesia

fizzyandriani@dsn.moestopo.ac.id

Article History: Received 2019-10-29, Revised 2020-06-15, Published 2020-07-30

\begin{abstract}
The purpose of this study is to look at the phenomenon of celebrity on social media Instagram and relate it to the hyper-reality theory by Jean Baudrillard. The vast expression space provided by online media has led to a wave of folk culture that allows anyone to become a producer and consumer of texts. Clothing recommendations are now much oriented on the celebrity fashion hijab. The problem is whether this celebrity hijab fashion is an accurate representation of Instagram users, so users often imitate the style of the role model. This study uses the theory of hyperreality, the concept of social media, and celebrity on Instagram. This study uses a post-positivist paradigm, qualitative, and quantitative approaches. The unit of analysis in this study is the followers of hijab fashion celebrity's Instagram. Data collection techniques are an in-depth interview and survey. The results showed the level of representation in Baudrillard's terminologywhich includes (1) representations that lie behind facts, (2) representations that cover facts, (3) representations that do not have facts, and (4) representations that are not related to facts-and identification of reasons for joining certain celebrity fashion hijabs. The literacy point emphasizes on what is shown by 'celebgram' is not the actual reality. It is just a representation that refers to 'itself' and not for others. Impersonation can produce a range of satisfaction for disappointment.
\end{abstract}

Tujuan penelitian ini adalah melihat fenomena selebriti Instagram dan kaitannya dengan teori hyper-realita dari Jean Baudrillard. Ruang ekspresi yang terbuka luas akibat perkembangan media online, menyebabkan terjadinya gelombang budaya akar rumput yang memungkinkan siapa pun untuk menjadi produsen dan konsumen teks secara bersamaan. Hal inilah yang memungkinkan siapa pun untuk menjadi 'ahli' di bidang yang mereka kerjakan atau sukai, dan fashion jilbab adalah salah satunya. Rekomendasi mode banyak berorientasi pada jilbab fesyen selebriti di Instagram. 


\begin{abstract}
Masalahnya adalah apakah busana hijab yang dikenakan selebriti di Instagram ini merupakan representasi sebenarnya dari pengguna, sehingga pengguna sering meniru gaya para selebgram tersebut. Penelitian ini menggunakan teori hyperreality, konsep media sosial dan selebriti di Instagram. Penelitian ini menggunakan paradigma postpositivis, pendekatan kualitatif, dan kuantitatif. Unit analisis dalam penelitian ini adalah followers selebgram hijab fashion. Teknik pengumpulan data adalah wawancara mendalam dan survey. Hasil penelitian yang diperoleh adalah tingkatan representasi dalam terminology Baudrillard-yang meliputi (1) representasi yang berada di balik fakta, (2) representasi yang menutupi fakta, (3) representasi yang tidak ada faktanya, serta (4) representasi yang tidak berhubungan dengan fakta-dan identifikasi alasan para followers mengikuti gaya selebgram tertentu. Aspek literasi yang ditekankan dalam penelitian ini adalah pada apa yang ditunjukkan oleh 'selebgram' sejatinya bukanlah realitas yang sebenarnya. Itu hanya representasi yang merujuk pada 'dirinya sendiri' (selebgram) dan bukan untuk orang lain. Peniruan identitas dapat menghasilkanskepuasan atau justru kekecewaan.
\end{abstract}

Keywords: Hyper Reality, Representation, Celebrity Hijab, Instagram.

\section{INTRODUCTION}

Digitalization of media is an inevitable consequence of technological progress. Its progress is not only in its increasingly concise form but also in its increasingly diverse and interrelated content. A gadget such as a cell phone can even deliver its users virtually to whatever interests them in their lives. Electronic media has entered a period of convergence of various types, especially in terms of visualization, sound, touch sensation, to various user interests. The presence of computers (in media devices) sums up data transmission and processing to produce an extraordinary convergence effect in the communications industry (Kitler, 1997 Manovitch, 2001 in (Loon, 2007)). Convergence not only occurs in hardware, software, and content also experience the same thing. They are integrated and access each other based on inclusiveness. Users and producers also share and exchange roles because the convergence of media in the advancement of communication technology has blurred many exclusive roles that were only used by certain people.

The information shared through the social media were more effective in affecting the behaviors and purchase intention of consumers (Labrecque, vor dem Esche, Mathwick, Novak, \& Hofacker, 2013). Celebrities are considered as being the persuasive element in marketing, but celebrities in current Ads are not enough credible to be believed upon for purchase intention, as analyzed by Hassan and Jamil (Jamil \& Hassan, 2014). Based on the results of the Hermanda et. al's research, social media influencers had a significant positive effect on the brand image of local cosmetic products and consumers' self-concept (Hermanda, Sumarwan, \& Tinaprillia, 2019).

An article in Koran Tempo explained the role of fashion bloggers in the world fashion industry. They were invited to prestigious fashion moments at the local scope and abroad, endorsed with certain brands, and even asked to demonstrate clothes from various brands in their respective tastes and styles. 'Unusual' fashion styles, as well as their ability to review fashion materials, make them 'idols' new fashion in the world of digital fashion in blogs, and the social media they use. Their followers reach hundreds of thousands to millions of people, and their comments become a reference for many fashion houses in the world to launch their newest model series (Hakim, 2016).

In the culinary world, various restaurant reviews and food stalls can be found on the zomato.com. This independent site that contains reviews of food, places, prices, to the atmosphere as desired by culinary lovers. Not only that, but the managers on this site also rank the restaurant list to the preferred street food based on input from loose reviewers 
every week (Zomato, 2016). Communities that were not initially accommodated in conventional media also grew along with the development of this converging digital media - starting from the controversial ones such as the gay and lesbian community, to the community of fathers supporting breastfeeding (ASI) who are members of the \#ayahASI community.

With this description, it can be seen how there is no longer the role of the middlemen (Jarvis, 2011), or professional critics because even the role of amateurs is taken into account. Converging media with a variety of diverse data successfully obscured the criteria of authority (reputation, expertise, and institutional guarantees), because amateurs can establish closeness with the public (Bennett, Kendall, \& McDougall, 2011). At this stage, amateurs can even become 'driving machines' to influence other grassroots users.

In general, the massive business world feels the most positive and negative impacts of the presence of this convergence media. Its interactive nature and fast access make it easier for marketers who want to get to know their consumers more closely, while at the same time streamlining promotional costs by utilizing a different database (Safko \& Brake, 2009) On the other hand, consumers become active actors to find and customize content to their needs (Jenkins, 2006). Thus, producers and marketers are no longer central because consumers hold 'control' because of their selection.

In this section, it is seen how digital media can bring together the creativity of 'folk culture' (folk culture) originating from the grassroots with capitalist mass culture wrapped in certain brands, which in turn produces a unique 'convergent culture' (Jenkins, 2006, p. 135). That is why this converging digital media presenting a hybrid world'(Bennett et al., 2011), a world where various cultures boil down but remain in the path of uniqueness that maintains their context and locality.

According to predictions, several media trends that will continue to survive are web content, mobile content (commercial applications), commercial content, marketing content, digital marketing, online videos (outside Youtube), social media, ebooks, content analysis, and big data. In this context, it can be seen how many new job gaps are open because of the technological demands. Besides, professional and amateur media workers are in two different lanes but heading towards the same estuary. Public participation can provide other perspectives in the information conveyed by professional media workers so that the user's point of view is more complete and cover both sides can be realized.

It is where the role of Instagram celebrities becomes essential. Instagram celebrities or 'selebgram' are titles that are only known in Indonesia. They are people with various professions who have an extensive base of followers. Each participant usually has 'special expertise' in specific fields, which then becomes the central review in their accounts. Such as fashion selebgrams, food and culinary (Ginsberg, 2015), healthy menus, to matters relating to religion. They influence almost in many fields, such as attitudes towards e-cigarette and smoking intention (Phua, Jin, \& Hahm, 2017), until lifestyle. The celebrity's endorsers credibility has significant influence toward purchase intention. Attitude toward the brand is the most influencing variable in order to lead the customer purchase intention. (Nugraha, Kusumawardani, \& Octavianie, 2018)smartphone or tablet already becomes part of people life that cannot be separated in daily activity. Driven by healthy life style and technological life style, 3 Skinny Minnies appears to be one of the player in providing healthy food to its customer and utilizing social media as distribution channel such as Instagram to promote their product. In promoting healthy life style by providing healthy food, 3 Skinny Minnies consistently utilize celebrity endorsement to become content of Instagram feeds. This research analyzes the effectiveness of celebrity as endorser in influencing purchase intention by attitude toward the brand using 
quantitative approach which, the primary data were collected from the respondents through online questionnaire. There were 274 respondents as a sample size of the research and through validity and reliability analysis that processed by statistical software using factor analysis and structural equation modeling. Based on the data analysis, it is found that celebrity endorsement has low influence on purchase intention even though the attitude toward the brand has significantly influence the customer. Hence, attitude toward the brand in this case has a direct influence on purchase intention. Thus, in order to win the competition, it is important to improve the way 3 Skinny Movies in promoting the products, so that the activities will be more effective in generating revenue. (Nugraha, Kusumawardani, \& Octavianie, 2018. Celebrity endorsement in advertising can bring better communication results than the use of ordinary persons, experts or anonymous models, and that physical attractiveness of the communication source is significant for product categories associated with this characteristic (Karasiewicz \& Kowalczuk, 2015)if present, do these positive effects vary by product category? To answer these two questions research was conducted on a 237 student sample employing a quasiexperiment consisting of four groups (two product categories and two types of endorsers. In the fashion industry, selebgram influences consumer behavioral intentions toward both the influencer (intention to interact in the account and recommend it) and the fashion industry (intention to follow fashion advice posted) (Casaló, Flavián, \& IbáñezSánchez, 2018). Particularly for millennials who often evaluated an unfamiliar celebrity endorsement where they indicated they had little intent to purchase the product endorsed by the unfamiliar celebrity. However, the unfamiliar celebrity did lead to favorable evaluations of the advertisement (McCormick, 2016).

The type of endorser that has been gaining traction in marketing lately, namely social media influencers. One of the biggest challenges in influencer marketing is the identification of the right influencers. But a high number of followers may not always translate into true influence. Although it is tempting to choose an influencer with a high number of followers in any case, this would not be the best marketing option for each product type. Therefore, the topics influencers post and the audience they reach in terms of interests and activities, rather than the size of their audience might be more important to take into account. (De Veirman, Cauberghe, \& Hudders, 2017) partly because they are considered more popular. Important, only in limited cases, perceptions of popularity induced by the influencer's number of followers increase the influencer's perceived opinion leadership. However, if the influencer follows very few accounts him-/herself, this can negatively impact popular influencers' likeability. Also, cooperating with influencers with high numbers of followers might not be the best marketing choice for promoting divergent products, as this decreases the brand's perceived uniqueness and consequently brand attitudes.(De Veirman, Cauberghe, \& Hudders, 2017

Influencer endorsements are more effective than celebrity endorsements, which can be explained by processes of wishful identification, similarity, and identification. An endorsed product must be able to enhance feelings of similarity and wishful identification. Moreover, an influencer must elicit trust in order to be effective. Influencers are not deemed more knowledgeable than celebrity endorsers, and expertise does not explain why influencer endorsements may be more effective than celebrity endorsements. Product-endorser fit has no effect on the relationship between type of endorsement and trust, expertise, or advertising effectiveness, although the effectiveness of influencer versus celebrity endorsements hinges upon specific influencer product combinations that elicit feelings of similarity, identification, and trust. (Schouten, Janssen, \& Verspaget, 2019)

The market value of celebrities who become Instagram influencers is usually 
proportional to the number of followers they have. Many brands use users (ordinary people) on Instagram for advertisements and product endorsers by paying them based on the number of followers they can reach, or the number of potential consumers who will find the contents of the celebrity. To increase the number of followers of celebrities who are authentic accounts, these celebrities are diligently cleaning up "fake followers" or fake accounts, which function as 'click farms' - a term for gaining followers in huge numbers (Abidin, 2018). This effort they need to do to maintain the credibility of the account selebgram concerned, although not a few 'naughty selebgram' who are willing to buy millions of fake accounts to increase their selling value in the eyes of clients.

In the realm of hijab fashion in Indonesia, at least some names are known to be influencers. Those who were initially known for their expertise in specific fields later became very popular in the field of hijab fashion because of the clothes they wore. Refer to one article; seven Instagram celebrities were hired as hijab fashion recommendations in Indonesia. They are Ayana Jihye Moon (@xolovelyayana, 2.4 million followers), Indah Nada Puspita (@ indahnadapuspita, 681 thousand followers), Mega Iskanti (@megaiskanti, 699 thousand followers), Tantri Namirah (@tantrinamirah, 304 thousand followers), Jenahara Nasution (@jenaharanasution, 373 thousand followers),Dwi Handayani (@dwihandaanda, 974 thousand followers), and Hamidah Rachmayanti (@hamidahrachmayanti, 980 thousand followers) (Natasya, 2018).

The seven celebrities of hijab fashion have posted not only endorsing fashion products, but also other things in their daily life, such as the content on holidays, weddings, children, hobbies, culinary tours, and so on. Interestingly, two of these celebrities also have their fashion brands. However, this did not prevent other fashion brands from becoming their endorsers. Even if they have to introduce one of the other fashion brands, they will take an exclusive photoshoot and mention the product in the narration that has been arranged by their respective teams.

In this way, their professionalism is maintained by displaying visual and narrative qualities that are following the wishes of the client. Not surprisingly, in a few moments, the celebrity posts will gain lots of likes and brands that they introduce immediately get a response (purchase, and / or questions). Remarkably, this post does not 'stop' at followers of celebrities. Accounts that are related to the personal accounts of celebrities, followers, and brands that are introduced will get the same exposure. In this way, the brand is increasingly known, and the easier it is to get a 'profit.'

The problem is, will use the same brand produce the same reality representation as to the celebrity? However, celebrities use certain brands because there is indeed a flow of economic capital between themselves and the brand concerned, while followers usually buy voluntarily. Selebgram is a representation of the advertised brand. They selections as far as possible represents everything related to the brand, such as body shape, activity, number of followers, and track record of posts they have ever done. As far as possible, they are the personification of the brand with a speech that is indeed a specialty of the celebrity. Therefore the narration and visuals of each post regarding the fashion brand are managed in such a way as to attract the attention of followers. However, are hijab fashion selebgram is representation of followers who are willing to buy the brand advertised by the idol? This is the problem question raised.

Baudrillard called it the level of representation. He is one of the postmodern figures who have excellent attention to the culture of a society in the digital age. His early writings on the simulations and theories of simulacra were regularly changed by Baudrillard himself and his followers to analyze the cultural and political impact of communication technology. Baudrillard also believes that his analysis of media and pop culture applies to studies of the cultural impact of virtual technology and computermediated communication (Matrix, 2006) 
and explains how some key concepts (such as 'virtuality,' 'speed,' and 'Connectivity' . From this question, the goal to be achieved is to identify; (1) The level of representation displayed bycelebrityhijabsin their Instagram accounts-which includes representations that lie behind facts, representations that cover facts, representations that do not have facts, and representations that are not related to facts; (2) Literacy points that need to be emphasized based on the findings.

\section{LITERATURE REVIEW}

\section{Hyperreality in Advertising in Digital Media}

The term hyperreality is the terminology that Jean Baudrillard uses to describe representation. In hyperreality, the signifier becomes the sign itself because the facts have been simulated. With simulation, reality becomes more 'real' than the reality. It is so difficult to distinguish, even according to Baudrillard, 'current reality is hyperreality itself'(Loon, 2007).

Hyperreality and simulation are the 'opposite' of one reality. Often they even turn against this reality for a while. Ultimately, hyperreality destroys every reference, flips through the rules, until it rejects all single truths and binary opposition. Once the 'reality' is reality compared to reality, it also liquidates and annihilates all use-values, with extraordinary manipulation abilities. At certain times, hyperreality can multiply the signs and speed up the simulation game, until people are sure about what they see/ hear (Baudrillard, 1994).

Thus, true hyperreality is indeed not reality. It is only a representation of reality. Imaging refers to one particular symbol. Therefore Baudrillard categorizes representations as part of hyperreality, as follows; (1) representation is a reflection of reality; (2) representation covers reality; (3) representation conceals that (in fact) there is indeed no reality; and (4) representation has no relationship with any reality, which Baudrillard calls simulacra (Baudrillard, 1994)
Baudrillard gave an example of a form of representation inadvertising. Advertisements according to Baudrillard do not refer to the real world or real (particular) objects, but advertisements 'work' from one sign to another, from one object to another, from one consumer to another. Hence that advertising is indeed a strategic point of the simulation process. Thus, advertising symbols are very likely to be changed. Advertising offers a form of discourse that combines various aspects of the continuum rhetoric, such as sounds, signs, signals, slogans, which are exciting and function as an extraordinary form of simulation (Baudrillard, 1994).

Technological advances and digitalization have made these aspects superfluous. Therefore, the 'absence' (meaning) in the sign that it represents, it becomes a very interesting and a mirror for a variety of significant public (audience). In other words, advertisements present many simple signs and symbols that swimmers can easily recognize, but at the same time let the public construct various meanings on them. It is natural to refer to advertisements as superficial, saturated, but attractive.

Therefore, it is useless if the meaning of advertising isonlylimited tolanguage because there is something going on there: ambiguity language (or pictures) that does not refer to any language or science of semiology because it operates on the real meaning (which is not affordable). Thus, it is not enough to interpret advertising as a form of commodity or claim it in a territory of a certain meaning (Baudrillard, 1994). It appears that the real advertising in commodity terminology is not something real. It 'plays' itself in the codes that are most easily recognized by the public to help then it leads to one specific (advertiser) intent. In otherterms, advertising is even accommodation of various disciplines because of its breadth in using symbols with many meanings. Duration and limited space become a significant arena for advertisers to represent advertiser's intent in many symbols so that the intent is still achieved without having to say much. 


\section{Celebrities on Instagram ('Selebgram')}

The phenomenon of celebrity on Instagram grows along with the growth of content on social media. Its great role as an influencer is said to be able to drive profits and action trends for many commercial and non-commercial interests. They are often not public meanings or figures, but instead, most people have many followers (subscribers or subscribers) because their social media content is interesting, funny, and even pithy. It is often through the content of social media celebrities that the flow of economic capital revolves through content channels in their social media accounts. Many kinds of literature mention these social media celebrities as micro-celebrity, while in Indonesia the popular term 'selebgram' is known.

These celebrities are a real form of entrepreneurship, with forms of collaboration and techniques of self-presentation to selfpromotion, which are well known since the 2ooos. "Micro-celebrity"; is a strategy that combines micro-entrepreneurs with big business, and executes them in marketing and advertising techniques that focus on businesses supported by celebrity culture. Social media changes economic relations in the form of everyday symbols - which are easier to enjoy and more quickly accessible - in the form of life-streaming as well as other images in the content of the celebrities (Marwick, 2013). The fastest response that is immediately visible and measurable is through the number of 'likes' given by their followers.

Internet celebrities are products of performance and perception. It is often done intentionally by a business entity or individual who has the intuition that internet celebrities are indeed liked because of their quality. Although the texts he produces are arranged in such a simple way - the ability of these internet celebrities to package their exclusivity, exoticism, existence, or daily life is what is considered 'quality' in the eyes of the public (Abidin, 2018, p. 19). If we use Pierre Bourdieu's terminology of capital, then these celebrities are people who have high social capital. Social capital is based on social relations between individuals and other individuals. It refers to the ability of agents to practice symbols in expressing and maintaining their position in the arena (Bourdieu, 2007), in this case, the field of social media. Even other articles mention the emerge of celebrity capital-as part of symbolic capital-to describe the celebrity on the Instagram phenomenon. (Driessens, 2013)

\section{METHODS}

This study uses the post-positivist paradigm as a guide to the logic of researchers' thinking. With this paradigm, researchers need a mix-method with a qualitative as well as a quantitative approach. In the implementation phase of a qualitative research approach, researchers used in-depth interview data collection techniques, supplemented by a survey with a questionnaire instrument for the quantitative approach. Thus, individual followers of the celebrity hijab fashion became the unit of analysis for this study. Quantitative data describes the trend of follower attitude upon their selebgram actions, while qualitative data crawls deep thought and the reason behind the followers' opinion. A frame of the population in this study were university students in South Jakarta for the reason of researcher efficiency. University students are chosen as the unit of analysis because they have a similarity in age with the selebgrams. The sampling technique was based on a non-probability technique with purposive sampling forgetting specific information from the 50 respondents while in-depth interviews conducted to three female university students who had many experiences in shopping hijab fashion recommended by selebgram.

\section{RESULTS AND DISCUSSION}

In the initial research, it was identified that many celebrities liked by respondents. The profession of those celebrities are also varies. Both from among well-known artists such as Zaskia Adya Mecca and Zeze Shahab, some celebrities are also fashion influencers like Indah Nada Puspita, and there are also 
those who work as celebrities who endorse several fashion brands such as Mega Iskanti and Nisa Cookie. The informant who was interviewed in-depth turned out to be a follower of the account of their favorite Instagram celebrities.

This is also reinforced by quantitative results that show thetendency of respondents' interest in hijab fashion selebgram who advertise products from particular brands on Instagram, as illustrated in the following chart;

Chart 1. Interest in Seeing Selebgram Wearing Fashion Products in Certain Online Stores

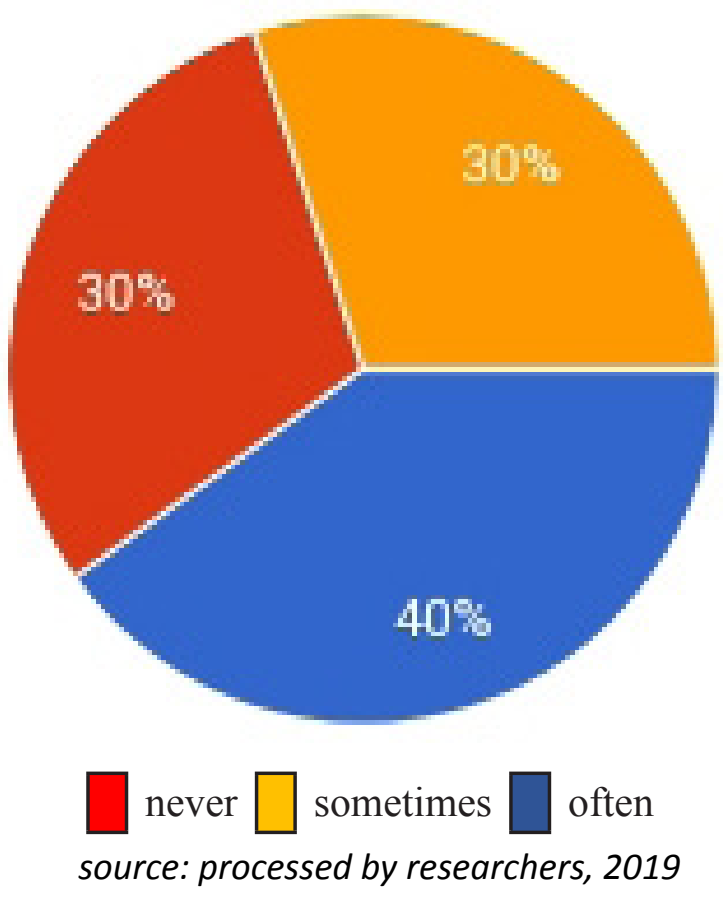

These results above indicate that respondents are easily attracted to celebrities when they use certain brands. This initial data was also strengthened by the following data which showed the tendency of spending actions undertaken by followers of this celebrity account as well as seeing their idols using certain fashion brands;

\section{Chart 2. Shop for Fashion Products via Instagram After Saw Selebgram Wearing It}

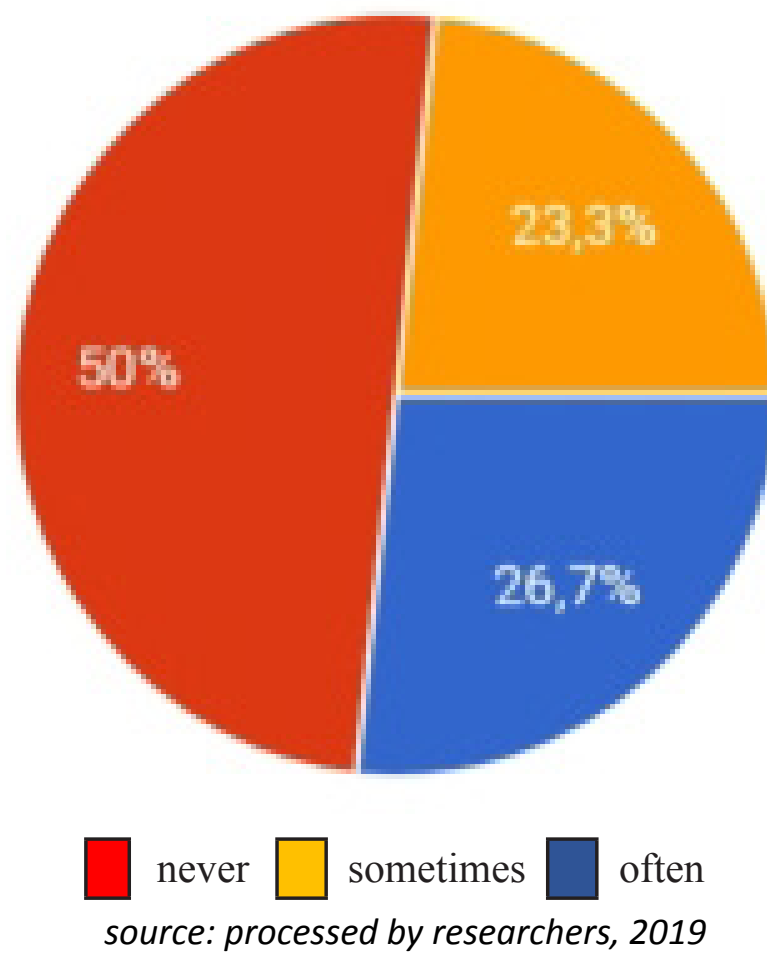

These preliminary findings show that more than half of the teenage respondents surveyed sometimes make purchases of individual fashion brands after celebrities wear them in posts on their respective accounts. The initial response of followers to celebrity posts is to always give 'likes' to the posts they like, even though they do not comment on the celebrity posts. However, if they are interested, then photos of the selebgram with the fashion they wear will be saved (screen capture), and then the followers will order it themselves. If the celebrity wears fashion products from a particular brand, and the informant/follower is interested, the follower will open the account page for the fashion brand. It shows how the celebrity can influence followers to carry out a sequence of actions; log in to Instagram accounts, follow celebrity accounts, and even buy their products, as stated by this informant;

"Just make inspiration and look for benefits, not just follow selebgram's account. Yes (will buy) if suitable and useful", (HY, 21 years old).

In in-depth interviews, it was also confirmed that all informants had often even bought fashion products worn by the 
selebgram, with an average frequency of two until five times to more than ten times ordering products that were subjected to their favorite selebgrams. However, followers also still have some criteria for finally deciding to buy products that are subject to registration. In general, they will buy products if they are interested and feel they are suitable for the style, and the price is affordable, as stated by these informants;

"I did because it was just the same as what else I needed or what I was looking for", (HY, 21 years old).

"The reason is that I am interested in trying the hijab they endorse from the words they use. Moreover, I feel that I will need it for reference at any time", (UC, 19 years old)

The celebrity dress style 'mix and match' colors, motifs, shapes, to make fashion look modern and fresh is what attracts the attention of followers. This style according to the followers has similarities with their selves, as illustrated in the following chart;

Chart 3. Feeling Similarity with Celebrities Who Wear the Same Products from Certain Brands
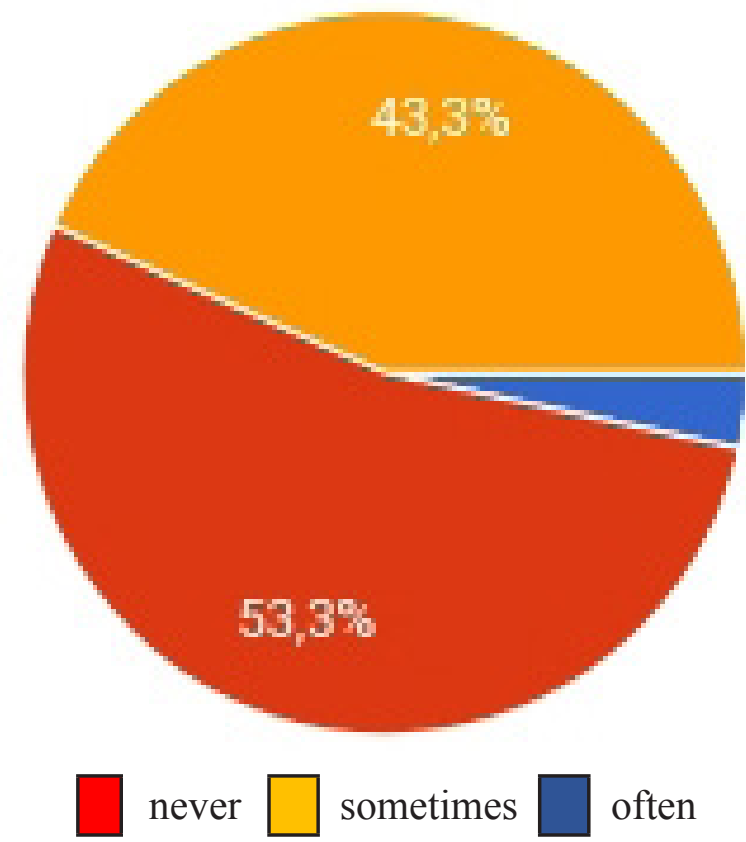

source: processed by researchers, 2019

'Similarity' at least shows that the respondent was represented in a celebrity style when wearing the same fashion brand. Although not personally known, 'similarity' is also an early indication of the reflection of followers with their idols in this case relating to the fashion brand worn. The reasons for respondents were liking celebrities vary, but in general, they like these celebrities because they are considered to have similar characters in the dress with themselves, as stated by this informant;

"Not at all, anyway, besides celebrities, there are also many ordinary people (dressed in style) just because they are famous so it's easier to find them", (TY, 20 years old).

In in-depth interview, it was revealed, if the followers' fashion tastes were clothes that were closed and not see-through, then they would also tend to choose celebrities who display photos that were also covered and not see-through. Selebgram style that is preferred is also a style that is considered pure and not excessive. This simple and modest style brings the distance between the celebrity and their followers because that is the assumption of their daily appearance. This fact shows that the real followers are 'picky'. They do not necessarily imitate (mimicry) directly the idol style, but look for the one that best, reflects their styles, and purchasing power.

It is undeniable, followers feel happy after successfully getting the product worn by the celebrity on Instagram. The further reaction is indeed different. Some immediately post when wearing the product and 'tag' the selebgram account, some are just posting without tags or explanations about the products they wear. Even more severe, respondents also volunteered to recommend to other brands that were subjected to such a fashion hijab, as shown in the following chart; 


\section{Chart 4. Recommend to Others about Fashion Brands Worn by Selebgram}

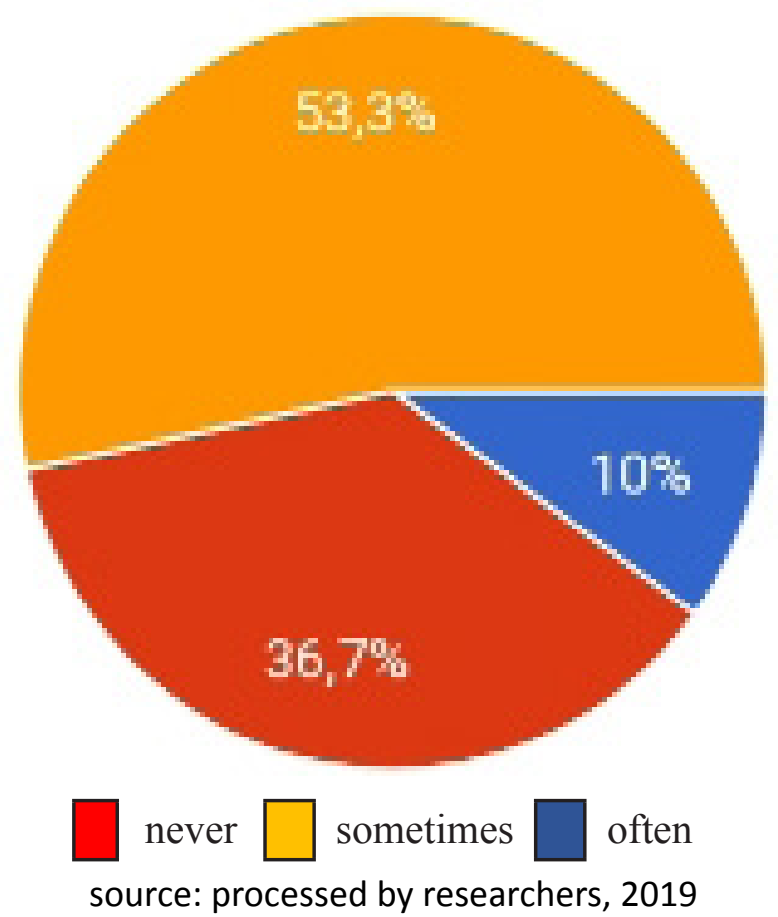

This data shows that high reflection from followers on the selebgram will produce the confidence to make followers also influencers for their followers with the rerecommendation. In other words, followers become representations of the individual reality of other followers. This happens because followers have always been satisfied with the products they buy after being worn by a celebrity on their Instagram account. Based on the results of the interview, followers also have never felt disappointed after buying the reference product of the selebgrams.' However, followers have indeed chosen a selebgram that they believe in. This is not without cause. Previous followers have experienced disappointment when shopping online that is not based on selebgram references. Usually, because the products they receive do not match as promised. Predictably, in the next stage, followers are more careful in choosing products especially fashion - on Instagram. In the end, the selebgram factor, more or less did form their trust in choosing the product.

The results of the study at least indicate that the representation produced by the selebgram in communicating the fashion brand hijab succeeded in reflecting the reality of followers in the appearance that was worn. Although it is a display of hyperreality in the form of visual and narrative structuring simulations that are tailored to the desires of the brand owner's producers, selebgram are still considered capable of providing fashion recommendations for their followers. One reason is that celebrity styles that are not excessive and capable of mixing and matching clothes are considered to be the same as the followers' daily fashion. In this section, at least the simulated selebgram is in the first stage, according to Baudrillard's terminology, which is a representation that reflects reality.

On one occasion, the simulation that was displayed could also be in the second stage, namely a representation that covered reality. For example, if a celebrity still has to comment well on products that are actually of poor quality. This is possible because the relationship between producers and selebgrams are business relationships based on content monetization. As far as possible, the selebgram applies per the demands of the manufacturer. In this section, celebrities are also treated as 'commodities' that sell every aspect of their lives - to very personal things, such as pregnancy and childbirth - to attract the participation of followers (Hornsby, 2018, p. 188). The hyperreality point that is played is if a selebgram displays a simulation of excitement, the pleasure of wearing these products. Even though no one can guarantee that celebrities use these products in their daily lives.

However, the practice of simulation in digital media is simulations that meet all levels of representation according to Baudrillard's thinking. The representation can be a reflective form of reality, covering reality, not related to reality, or there is no reality. This is what was tried by fashion producers. They believe that large-scale retail business is not an option because it is 'away' from consumers. Because anything that allows humans to organize networks of mass cooperation is certainly not an intimate relationship (Harari, 2017). The choice of using a selebgram with a follower basis is 
the right option to produce the expected impact (profit). For these producers, celebrities are resellers who are contextual, sporadic or specific to specific target genres or cohorts, have a special relationship (with followers), and of course, have the ability of 'recommendations being heard' by their followers.

From the consumer or follower side, interactions occur not only with the selebgram or producers, but also discussions with other consumers. This is where literacy is done accidentally by followers. Selecting celebrities and brands that are worn, considering whether the fashion is suitable for them, and then deciding to buy or not, are forms of literative behavior that is not realized. Therefore, for producers, testimony and trust are essential capital producers who rely on this social media (Safko \& Brake, 20o9). Good testimonials that come from celebrities, as well as followers. A testimony related to brand complaints from a company can even change the way the company serves its consumers. Until in the end, consumers are no longer merely final consumers but have become an essential part of the company. By several multinational companies, consumers have even become partners and friends who can also deliberately express their ideas in determining product development (Jarvis, 2011). In a networked society, conventional media work - which was very powerful initially-is no longer the sole cause in shaping individual character. Thus, individual selfconcept is often no longer merely formed by the agents of socialization that surrounds it but also based on affirmations and confirmations to the community in which they associate and the social relationships they have (Castells, 2009). That is, massive advertising and products - without regard to context - are no longer interesting if in this digital world, which can then be the forerunner of the death of many commodity agencies and companies in the world. Creating a niche or looking for a market gap that customizes many products to the desires of consumers, is believed to be a form of marketing today and the future (Jarvis, 2011).
This section at least describes the recesses of hyperreality that are open and widely used by celebrities in various fields: fashion, philanthropy, hobbies, culinary, and so on. Because accustomed, selebgram can easily simulate reality in such a way, alternating roles and (even) preferences, according to the needs of monetization. In general, here is an overview of the business flow that is played by a selebgram based on the simulation performed;

\section{Chart 5. Business Flow of Producer- Hijab Fashion Selebgram -Followers and Simulations Performed}

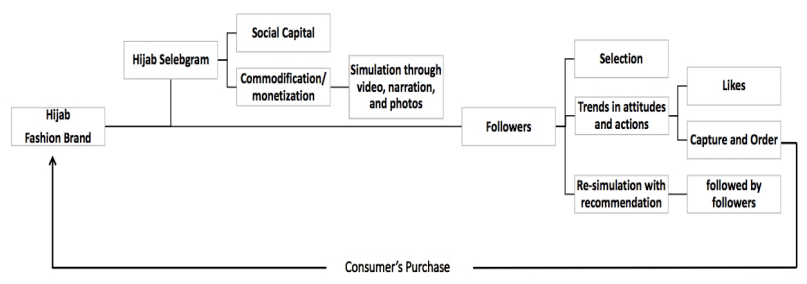

source: processed by researchers, 2019

The chart at least shows that each actor in the business has an equal position when he is on social media. This is in line with the discussion about technology. Ethics is the most pertinent to the organizational and cultural aspects of technology, as is the Arnold Pacey trilogy.(Pacey, 1983) This ethic at least leads to literacy, both of which are undertaken by producers in choosing selebgram that suits the context of the product, selebgram herself, and followers. It cannot be denied that in innovation, at least technology companies still pay attention to three central values relating to technological practices: the value of expertise, economic value, and thevalue and needs of users. Where ethics as a critical element surrounding all three (Pacey, 2000, p. 102). Ethics are usually present in a community or concerning the profession. If communication technology is related to media, then ethics stretches in the community of production, distribution, exhibition, and consumption (users). 


\section{CONCLUSION}

From the findings, it was identified that fashion hijab selebgram considered to meet the first level in the representation that is part of the simulation or hyperreality in the terminology of Jean Baudrillard. Both celebrity and digital media can play this simulation to the fourth level, but the 'selection' as a literacy point by followers turns out to be able to withstand the hyperreality that 'only' remains at the first level. It is the selebgram that best reflects on followers whose testimonies are far more reliable.

\section{REFERENCES}

Abidin, C. (2018). Internet Celebrity: Understanding Fame Online. European Journal of Communication, 33(6), 696-697. https://doi. org/10.1177/0267323118814646a

Baudrillard, J. (1994). Simulacra and Simulation (The Body, In Theory: Histories of Cultural Materialism) (14th ed.). Michigan: University of Michigan Press.

Bennett, P., Kendall, A., \& McDougall, J. (2011). After the media: Culture and identity in the 21st century. In After the Media: Culture and Identity in the 21st Century. https://doi.org/10.4324/9780203817889

Bourdieu, P. (2007). Contemporary Sociological Theory. USA: Blackwell Publishing.

Castells, M. (2009). The Rise of the Network Society (2nd ed.). Sussex, United Kingdom: Wiley-Blackwell Publishing Ltd.

De Veirman, M., Cauberghe, V., \& Hudders, L. (2017). Marketing through instagram influencers: The impact of number of followers and product divergence on brand attitude. International Journal of Advertising, 36(5), 798-828. https:// doi.org/10.1080/02650487.2017.1348035

Driessens, O. (2013). Celebrity capital: Redefining celebrity using field theory. Theory and Society, 42(5), 543-56o. https://doi.org/10.1007/s11186-013-
9202-3

Hakim, S. . (2016, April 15). Gaya Fashion BLogger di Industri Maju. Koran Tempo.

Harari, Y. N. (2017). Homo Deus: A Brief History of Tomorrow (1st ed.). New York: HarperCollins.

Hermanda, A., Sumarwan, U., \& Tinaprillia, N. (2019). the Effect of Social Media Influencer on Brand Image, SelfConcept, and Purchase Intention. Journal of Consumer Sciences, 4(2), 7689. https://doi.org/10.29244/jcs.4.2.7689

Jamil, R. A., \& Hassan, S. R. ul. (2014). Influence of celebrity endorsement on consumer purchase intention for existing products: a comparative study. Journal of Management Info, 1(4), 1-8. https://doi.org/10.31580/jmi.v4i1.18

Jarvis, J. (2011). What Would Google Do?: Reverse-Engineering the Fastest Growing Company in the History of the World. New York: Harper Business.

Jenkins, H. (2006). Convergence Culture: Where Old and New Media Collide. New York: NYU Press.

Karasiewicz, G., \& Kowalczuk, M. (2015). Effect of Celebrity Endorsement in Advertising Activities by Product Type. International Journal of Management and Economics, 44(1), 74-91. https:// doi.org/10.1515/ijme-2015-0010

Labrecque, L. I., vor dem Esche, J., Mathwick, C., Novak, T. P., \& Hofacker, C. F. (2013). Consumer power: Evolution in the digital age. Journal of Interactive Marketing, 27, 257-269. https://doi. org/10.1016/j.intmar.2013.09.002

Loon, J. Van. (2007). Media Technology: Critical Perspectives: Critical Perspectives (Issues in Cultural and Media Studies. Berkshire, England: McGraw-Hill Open University Press.

Marwick, A. E. (2013). Status update: Celebrity, publicity, and branding in the social media age. In Status Update: 
Celebrity, Publicity, and Branding in the Social Media Age. https://doi. org/10.5860/choice.51-5062

Matrix, S. E. (2006). Cyberpop: Digital lifestyles and commodity culture. In Cyberpop: Digital Lifestyles and Commodity Culture. https://doi. org/10.4324/9780203959855

Natasya, N. (2018, May). Deretan Selebgram Hijab Indonesia Yang Paling Modis! Cosmopolitan Indonesia, 20-36.

Nugraha, R., Kusumawardani, K. A., \& Octavianie, V. (2018). The Influence of Celebrity Endorsement in Instagram towards Customer Behavior and Purchase Intention in Healthy Food Diet Business. Firm Journal of Management Studies, 3(2), 1-24. https://doi.org/10.33021/firm.v3i2.476

Pacey, A. (1983). The Culture of Technology. Cambridge Massachuset: MIT Press.

Safko, L., \& Brake, D. K. (2009). The Social Media Bible: tactics, Tools, and Strategies for Business Success. Canada: John Wiley \& Sons, Inc.

Schouten, A. P., Janssen, L., \& Verspaget, M. (2019). Celebrity vs. Influencer endorsements in advertising: the role of identification, credibility, and ProductEndorser fit. International Journal of Advertising, o(o), 1-24. https://doi.org /10.1080/02650487.2019.1634898 